\title{
Reform of Business English Talents Development Mode from the Perspective of Language Service
}

\author{
Liu Shan \\ School of Foreign Languages \\ Wuhan Textile University \\ Wuhan, China \\ susanliu212@126.com
}

\begin{abstract}
The rapid development of language service industry demands a large number of interdisciplinary business English service talents. Based on the analysis of the features of language service and present talent development mode, this paper proposes specific scheme for the reform of business English talents development mode in four aspects, namely, development goal, curriculum, teaching approach and connection between college and language service enterprises, and teachers should carry out the task-based cooperative learning to cultivate the students' service awareness. This paper also proposes to improve students' practical ability by using technology, to improve the quality of teaching and meet the needs of service, and to strengthen the link between universities and language service enterprises.
\end{abstract}

Keywords-Language service; Business english; Talent development mode

\section{INTRODUCTION}

Rapid growth of IT industry and globalization give rise to the springing up of localization, which in turn stimulates the development of language service industry, a newly-emerged industry which takes up an increasing part in outsourcing of international service since its emergence. According to 2016 Chinese Language Service Industry Development Report, "there are 72500 language and related service enterprises in China, among which 7369 specialized in language service, with output value exceeding 282.2 billion yuan in 2015, increasing by $79 \%$, compared that with merely 157.6 billion yuan in 2011, with annual increase rate of 19.7\%." [1]

The rapid development of this industry also draws the scholars' attention to language service and development of language service talents. Language service was defined in different ways. Language service system includes "translation and localization, development of language technology, language teaching and training."(Guo, 2010)[2]. "Language service, at micro level, refers to an activity which one party offers paid or free language service as content or tool and gain benefit from recipient. At macro level, it refers to effective allocation, planning and nomination by nations or governments to ensure reasonable and effective usage of language for all members within the region. (Li, 2010)[3, p16]. Mu (2013) points out that "Language service has expanded from interpretation and translation to various fields such as technical document writing, website localization, software localization and information processing of multi-language." $[4$, p89]
Therefore, language service industry, as an interdisciplinary emerging industry, requires support of inter-disciplinary talents, which in turn demands an improved talent cultivation system.

\section{Features of Language Service}

Different from previous language application, language service has three distinguished features: serviceability, utility and practicability, hence it has requirements for qualities of language service staff.

First of all, it requires language service staff to offer high-quality service effectively, consciously, actively because of its serviceability. Language service is by no means the simple language application for its recipients could be oneself or others, whereas recipients of language service are other people, the public or the society. Language service, therefore, could be categorized into tertiary industry, namely, service industry.

Secondly, language service staff is expected to be equipped with management knowledge and abide by management rules decided by its utility. This is because language service is a practical activity aimed at offering service and products rather than a theoretical study of language. A systematic management system is required to guarantee its long-term operation. Language service staff is required to be equipped with systematic managerial knowledge and obey management regulations.

Thirdly, language service suppliers should satisfy service recipients' demands by offering best products and service and focusing on the effect of service because language service's ultimate goal is the acquisition of actual products or service for service recipients, which is the essence of its practicality.

The special requirements for staff demands reform and innovation for universities in talent cultivation. High-quality language service talents contribute to the sound operation and development of language service industry need. Universities, as a result, are expected to have to adjust cultivation goal, curriculum and teaching methods and enhance its cooperation with enterprises. A systematic and professional program of language service talents is expected to be set. 


\section{Cultivation OF Business ENGlish TAlents FROM THE PERSPECTIVE OF LANGUAGE SERVICE}

Business English talents are an important part of language service personnel. With the progress of economic globalization, English language ability can no longer meet the need of complex language service activities, and the demand for English talents tends to be more comprehensive and diversified. As quoted from "2009 Teaching Requirements for undergraduate Business English Majors of Universities", business English talents refer to "interdisciplinary English talents engaged in business, trade and economics, management, finance and foreign affairs in international environment"[5]. Correspondingly, business English talents directly engaged in business language services, such as translation and localization services, language technology development, and so on, should be equipped with the basic qualities of language service talents. The proficiency of business English talents directly determines the success or failure of enterprises in the language service. Therefore, all colleges and universities in China have generally offered "Business English" undergraduate program. However, the traditional business English talents training mode featured with foreign language and basic business skills has failed to meet the needs of language service talents. The training mode of interdisciplinary and innovative business language service talents needs to be studied from the perspective of language service.

\section{A. Reconstruction of the Cultivation Goal for Business English Teaching}

Teaching Requirements for undergraduate Business English Majors of Universities specifies that the cultivation of "interdisciplinary English talents" is the goal of business English teaching. The so-called talents refers to "those equipped with solid English foundation, broad international vision, business knowledge and skills, mastery of basic knowledge and principles of economics, management and law and other related disciplines, those with higher cultural literacy and intercultural communication and communication skills." But this request was proposed before the rise of the language service talent industry. With the prosperity of the language service industry, the old cultivation goals could not meet the needs of the language service industry for business English talents any more. In addition to these basic theories and skills, business language service personnel should also have strong service awareness, basic knowledge of project management, mastery of translation skills, localization and IT skills. Business English service industry is characterized with practicality and utility. To be fully qualified for business interpretation or foreign trade business processing, business English talents should have strong practical ability, organizational and coordination ability, independent analysis and problem solving ability, information processing ability so as to fully meet the demands of customers. In face-to-face communication with foreign customers, they should also be skilful communicators with good service awareness. Only with these qualities can they meet the needs of the language service outsourcing enterprises that provide translation services and localization services for other enterprises.
To meet the demand of professional translators, translation technicians and translation mangers, universities may offer postgraduate programs in business English language service to cultivate senior language service talents with advanced translation skills, mastery of language-related technology and project management ability, who are also good critical and logical thinkers and problem solvers.

\section{B. Reform of the Course Setting of Business English Teaching}

At present, the College Business English Curriculum is generally based on the current "teaching requirements", offering courses related to language skills such as comprehensive English, listening, reading, writing and translation courses; and courses related to business English such as Business English, Business English Correspondence, International Trade, International Business Negotiation skills, intercultural communication-related Survey of English-speaking Countries and Guide to Intercultural Communication and liberal related British and American literature.

The curriculum is mainly based on the theoretical knowledge construction of English language and business, and the proportion of the practice courses is very small. The evaluation of students is also basically determined by the results of their theoretical courses. Such a curriculum system does not meet the needs of the language service industry for talents. As language services belong to the third industry which is of three characteristics, namely, service, practicality and utility, courses aimed at improving students' business management skills and service awareness should also be set, such as Introduction to Economics students, Introduction to Management, Marketing, Consumer Behavior, Consumer Psychology etc. Technology-related courses should also be included in curriculum, such as Computer-aided Translation Techniques, Management Software Applications. In view of the needs of software localization and website localization, industry-related courses, such as Computer English and Textile English should be included too. The proportion of practical courses should be largely increased, such as Business Communication Practice, Business Negotiation Practice, Project Interpretation Practice, Translation Project Management Practice etc. Performance in practice courses should be included into students' evaluation system.

\section{INNOVATION OF BUSINESS ENGLISH TEACHING METHODS}

Traditional Business English teaching is teacher-oriented, only focused on the sentence interpretation and text translation, which is therefore unable to meet the new requirements of the current language service industry. From the perspective of language service, business English teaching should adhere to the needs of language service industry, and effectively cultivate the comprehensive language service ability of business English majors. Therefore, teachers of business English should actively change their teaching ideas, reform the teaching methods and explore effective ways of training talents. 


\section{A. Carrying out the task-based cooperative learning to cultivate the students' service awareness}

In business English teaching, teachers should adopt the task-based cooperative learning. "Task-based cooperative learning is a learning mode aimed at fulfilling a task by group cooperation, which enables students to apprehend, use and interact so as to promote learning of all group members to a maximum extent. The primary concern is meaning, instead of form. (Liu and He, 2010) [6,p81]". Application of task-based cooperative learning to business English teaching improves fluency in language output, enhances students' sense of teamwork, and cultivates students' sense of service. Language service industry is not a private-workshop-style individual behavior, but a project-oriented team behavior, such as software localization project and website localization project. It requires team members to cooperate with the project manager to complete the language service project. In the process of providing language services, the service personnel need to have a strong sense of service. Service awareness refers to a kind of ideological consciousness that the practitioners understand the service and take the responsibility to provide paid labor from the heart. In Business English teaching, task - based cooperative learning could be adopted to simulate the real task of language service. In the process of teaching, teachers can divide students into teams, and complete the tasks from project acceptance, project task assignment to project acceptance under the guidance of team leader who is also the simulated project manager. Students take turns to play the role of group member, group leader and customer to fully experience each role in the project process. By alternately playing the role of service providers and customers, students can feel the difference between the roles of service providers and the recipients, whose service awareness is therefore cultivated.

\section{B. Improving students' practical ability by using technology}

Language service is a very practical activity, which requires students to have a strong practical ability. Teachers should make full use of technologies, such as multimedia, network training platform and so on, to cultivate students' practical ability. In the course of business English teaching, simulation laboratory and simulation software should be applied. The simulation software can be co-developed by the University and the language service enterprise. The teaching content can be taken from the authentic business cases. In the internet lab, students conduct simulated business interpretation, simulated international trade negotiations, simulated process of international trade documents, simulated international trade and custom declaration. For example, a Chinese language service company has developed a simulated translation training system, enabling students to simulate translation activities in various business situations on campus and make adequate preparations for future language services. Colleges and universities should formulate practice hours and time for business English program reasonably according to their own undergraduate programs.

\section{Improving the quality of teaching and meeting the needs of service}

The ultimate goal of language service is to meet the needs of its service object. In other words, it provides high-quality services and products for the service objects of translation and localization services, language technology development, language teaching and training. This requires students to have solid English skills, good business English skills and adaptability to various needs, and put forward higher requirements for the teaching level of business English. Business English teachers should flexibly design discussion questions based on language input materials, ask students to discuss group problems, and explore ways of solving problems from different perspective, so as to cultivate students' multiple innovative thinking mode. The critical-thinking-inspired and discussion-dominated teaching approach can promote the development of students' divergent thinking and creative thinking. The questions for discussion should be controversial and can lead to students' debate. For example, students analyze and discuss the English material of a case. "There is a stalemate in international business negotiations. The reason is that the price is $10 \%$ lower than the expected, but the five-year contract can be signed. However, if we stick to the expected price, the contract can only be signed for one year. Try to analyze how to break the ice in order to achieve the maximum interests? " Through this kind of problem, students not only improve their ability to use language materials and organize language, but also develop critical thinking of seeking different answers for solving the same problem. Both business English textbook writers and teachers should strive to explore the creative factors of real business materials, and create open questions by creating specific business scenarios, and encourage every student to participate in the discussion. The discussion of authentic business materials often stimulates students' interest in learning, which further stimulates the interest of their learning and improves the learning efficiency.

\section{Strengthening the link between universities and language service enterprises}

In order to cultivate business English talents to meet the needs of language service industry, colleges and universities should strengthen cooperation with language service enterprises. The cooperation between school and enterprise can be realized as follows:

\section{1) Language teachers' intern in language service enterprises.}

The language service industry has a high requirement for the overall quality of interdisciplinary talents. Many new courses involve economic management, trade, service and even the application of computer software. Many teachers lack the academic background and practical experience in these fields. In order to be qualified for the teaching of business language services, teachers themselves should not only grasp theoretical business knowledge, but also have practical experience in language service. Teachers may acquire first-hand information from enterprises on their demands for talents by their intern in winter or summer vacations so as to reduce the gap between talent training and the demand of enterprise, get familiar with the operation of language services process and improve their own language service level. With 
the intern experience, they will be more likely to be better guides for students to carry out simulated authentic language services activities.

\section{2) Employment of senior managers of language service enterprises as guest professors and social mentors}

Universities should also hire the senior managers of the language service enterprises as guest professors and social mentors. As a guest professor or social mentor, business managers may give case analysis lectures regularly, so that students can understand the possible problems and solutions in authentic language service projects, and they may help teachers carry out practical activities. Enterprises and colleges and universities can jointly develop business English service training courses, language service application teaching system and platform.

\section{3) Organization of students' intern in language service enterprise}

Language service has strong serviceability and practicality. The training of talents' service awareness and practical ability largely depends on the practice in enterprise. Colleges and universities should cooperate with language service enterprises by establishing student training bases in enterprises. Students' innovative ability and entrepreneurial ability are cultivated in practice, so that the realization of business English service personnel cultivation goals could be achieved. The school practice courses can be set as the transition of enterprise intern. After learning the process of the language service project through the training platform, the students will be more prepared for practice in enterprises. The practices on campus may centre around a large number of business translation and interpretation practices and simulated business scenes. Through internship, students personally experience the translation and editing, project management and other language service role, understand the operation of the entire project process, and improve service awareness of meeting different customers' needs.

\section{CONCLUSION}

In conclusion, the new language service industry needs a large number of interdisciplinary business English talents. Market-oriented innovation in talent cultivation mode of business talents is an unavoidable trend for colleges and universities. Only in this way can the link between talent cultivation and industrial demand be realized. It is essential to reform the business English talents' cultivation objectives, curriculum system, teaching methods and evaluation system based on the demand of language service industry. The potential problems in the reform and innovation will remain to be discussed.

\section{REFERENCES}

[1] 2016 Chinese Language Service Industry Development Report [EB/OL].http://ex.cssn.cn/dybg/gqdy_gdxw/201612/t20161226_335761 6.shtml. (In Chinese)

[2] Guo Xiaoyong, 2010, Development Status, Problems and Counterstrategies of Chinese Language Service Industry[OL], http://www.tac-online.org.cn/ch/tran/2012-12/03/content_5544437.htm.

[3] Li Xianle, 2010, On Language Services from the Perspective of Language Resources and Language Problems[J], Journal Of Yunnan Normal University (Humanities And Social Sciences Edition) (5): 16-21 (In Chinese)

[4] Mulei, 2013, On Improvement of Professional Translation Talents Training Mechanism from the Professionalization Perspective [J], Chinese Foreign Languages, (1): 89-95. (In Chinese)

[5] Chen Huaimin, Wang Lifei, 2009, Interpretation Of Teaching Requirements For Undergraduate Business English Majors Of Universities [J]. Chinese Foreign Languages (4). (In Chinese)

[6] Liu Shan, He Wei, 2010, Application of Task-Based Cooperative Learning in Intensive Spoken English Training [J], Textile Education (4): 81-83. (In Chinese) 